Bourne, M, C., CAMPBELL, D. R, and TANSLEY, K. (1938)-Trans. Ophthal. Soc. U.K., Vol. CVIII, i, p. 234.

Buschке; W. (1934).-Klin. Wschr., Vol. XIII, p. 178.5.

Collex, R. and Drouet, P. L. (1933).-Bull. Acad. Med., Paris, Vol. CIX, .p. 794 .

CunNingHaM Dax, E. (1938a).-Brit. Jl. of Ophth., Vol. XXII, p. 345.

(1938b).-Trans. Ophthal. Soc.U.K., Vol. LVIII, p. 227.

(1940).-Quart.Jl.Med., Vol. XXXIII, p. 263.

DUKE-ELDER, W. S. (1940).-Textbook of Ophthaimology, Vol. III.

GEILING; E. M. K. (1926).-Physiol. Rev., Vol. VI.

HOGBEN, L. (1924). -Pigmentary Effector System.

HogBen, L. and Gordon, C, (1930). Jl. Exp. Biol,, Vol. ViI, p. 286.

Hogben, L. and Landgrebe, F. W. (1940):-Proc. Roy. Soc.Med., Vol. CXXVIII, p. 317.

JORES, A. (1933) -Klin. Wschr, Vol. XII; p.. 1599.

JORES, A. and CAESAR (1935).-Pfluger's.Arch., Vol. CCXXXV, p. 724.

Jores, A. and Hotop, H. (1934), -Z. Vergl. Physiol., Vol. XX, p. 699.

JoRES, A. (1936):-Klin. Wschr., Vol. XV, p. 1433.

LANDGREBE, F. W. and WARING, H. (1941).-Quart. Jl. Exp. Physiol., Vol. XXXI, p. 31 .

- (1943a).-Quart. Jl. Exp. Physiol.

(1943b). - In press.

- Matuo, K. (1935).-Okayama Igak. Zasshie, Vol. XLVII, p. 2387.

MCDonald, P. R. and AdLER, F. H. (1942).-Arch. Ophthal., Vol. XXVII, p. 264.

Mclen A. J. (1928).-Jl. Pharm., Voi. XXXIIT, p. 301.

Nevinson, L. (1940)-Proc. National Acad. Sci. U.S.A., Vol. XXVI, (4), p. 257.

N.ICholls (1938).-Brit. Jl. Ophthal., Vol. XXII, p. 672.

Okanuto, T. (1937).-Zentralb. Ges. Exp., Vol. CI, p. 155.

RazA, S. H. and'SpurReli, W. R. (1937):-Jl. Physiol., Vol. XC, p. 429.

SORsBY (1940):-Modern Trends in Ophthalmology. London.

Thomson, A. M., GRIFfith, H. D.. MUtch, J. R. and LUBBock, D. M. (1939), Brit. Jl. Ophthal., Vol. XXIII, p. 461.

WAGENMÁN , A. (1890).- A rch.f. Ophthal, Vol. XXXVI, p. 4, Abt. 1.

WARING, H. and LANDGREBE, F. W. (194I).-Jl. Exp. Bioi., Vol. XVIII, p. 80.

ZONDEK, H. (1935).-Diseases of the Endocrine Glands. London.

\title{
WAR INJURIES OF THE EYE* \\ Traumatic Proliferative Choroiditis due to \\ Double Penetrating Foreign Body
}

BY

\author{
Major I. C. MiChaELSON, R.A.M.C. \\ and Dr. J. KRAUS
}

MANY eyes injured by a foreign body with an exit wound in the posterior part of the globe have presented the following fundal appearance after - the vitreous has cleared sufficiently to permit of detailed ophthalmoscopy. A white mass of varying size can be seen in the area of choroido-retinal atrophic change. The whiteness is frequently nilk-like and may be glistening with a few dots of crystalline brightness on its surface. The mass looks solid 
and in some cases projects far into the vitreous. It is not usually crossed by retinal arterioles or venules. Dark pigment may cover a part of its surface. The appearance suggests degenerative change following haemorrhage or else massive choroiditis. In some cases it looks like a foreign body.

In six of the following cases such an appearance is described. In the sixth case clinical observation was followed by a pathological investigation which suggests that the white mass represents a massive proliferative reaction to the trauma by the choroid. The pathological findings are described in a-seventh case where detailed ophthalmoscopy was not possible.

CASE 1.-P.M., aged 31 years. In January, 1941, this Italian P.O.W. received battle injuries to both eyes. The left eye had a large foreign body in the vitreous which was removed later by giant magnet through the anterior route. With a vision of $6 / 36$ this was destined to be ultimately the better eye.

The right eye had a double perforation of the globe as the result of a foreign body which finally lodged in the orbit. The entrance wound was indicated by a faint pigmented scleral scar $9 \mathrm{~mm}$. from the limbus at " 7 o'clock." Ophthalmoscopy showed a ridge of milk-white tissue extending from the periphery of the fundus in the lower temporal quadrant to a point down and out from the disc and about $11 \mathrm{~mm}$. from it. The anterior end of this ridge broadened out and corresponded in position to the scleral scar already noted. Fine capillary vessels were to be seen coursing over its anterior extremity. Later they appeared from the posterior extremity and from underneath the temporal margin. They had no apparent association with the visible retinal vessels which disappeared abruptly at the margins of the ridge. Later some white crystalline dots almost snow-like in brightness appeared on the surface. Papillitis with haemorrhages in the surrounding retina was present from an early date. Three months after coming under observation the retina was noted to be dotached above the ridge. A large dehiscence was present at " 3-4 o'clock." In June, 1941, diathermy operation was performed for the detachment. A barrage with surface applicators was made round the dehiscence. The detachment was replaced.

Fig. 1. is schematic of the path of the foreign body. Fig. 2 shows the fundal picture prior to the patient's departure to South Africa about a year after first coming under observation.

The white tissue did not alter much in size or in colour during the year under observation. During that period the vision of the right eye deteriorated from $6 / 18$ to $3 / 60$. The visual loss was probably chiefly due to the papillitis which never completely subsided. 


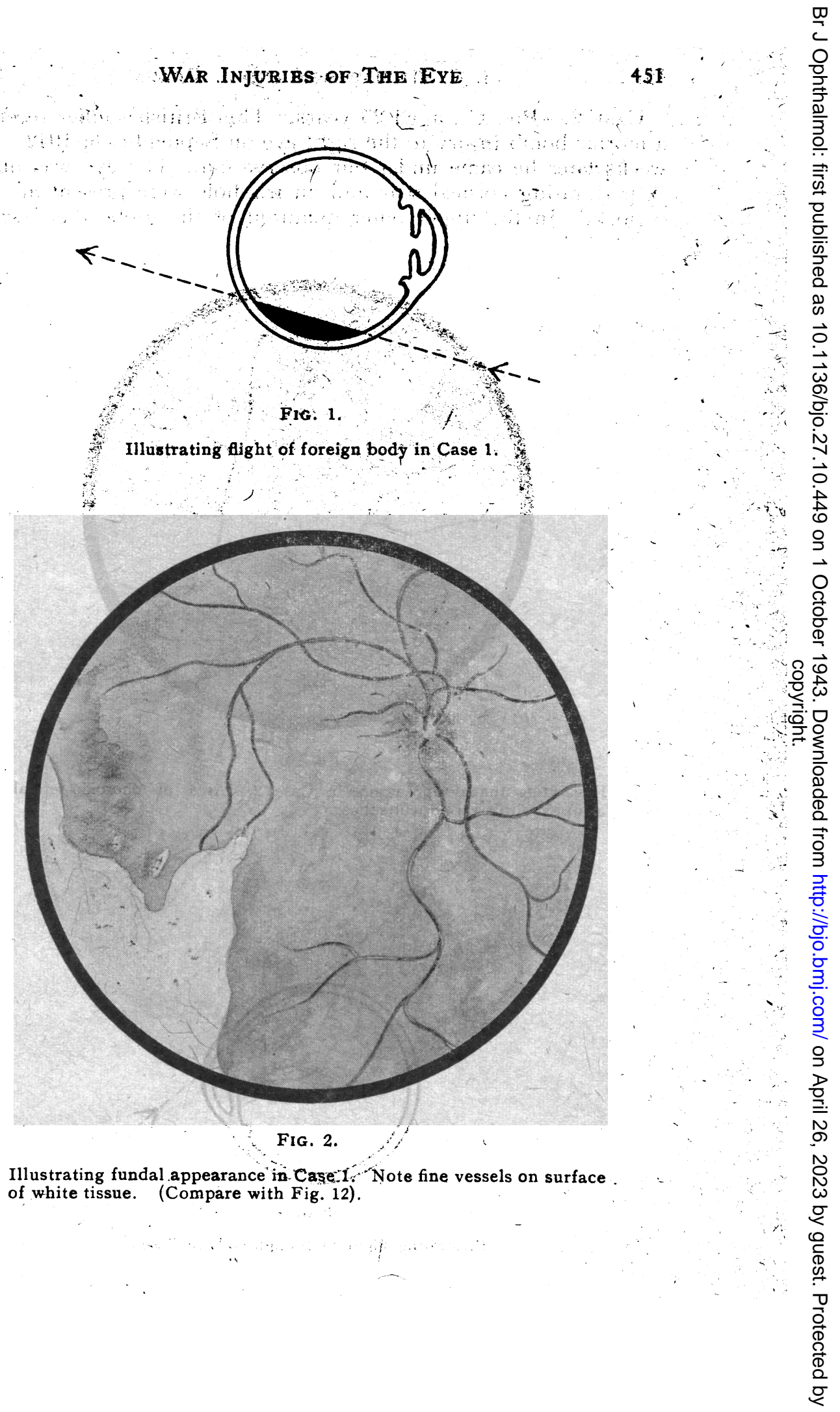


Case 2.-Pte. C., aged 29 years. This British soldier received a mortar bomb injury to the right eye on September 3, 1942. Six weeks later he came under our observation. The eye was quiet. A perforating corneal scar and an iris hole were present at " 10 o'clock." In the upper outer quadrant of the globe there was a

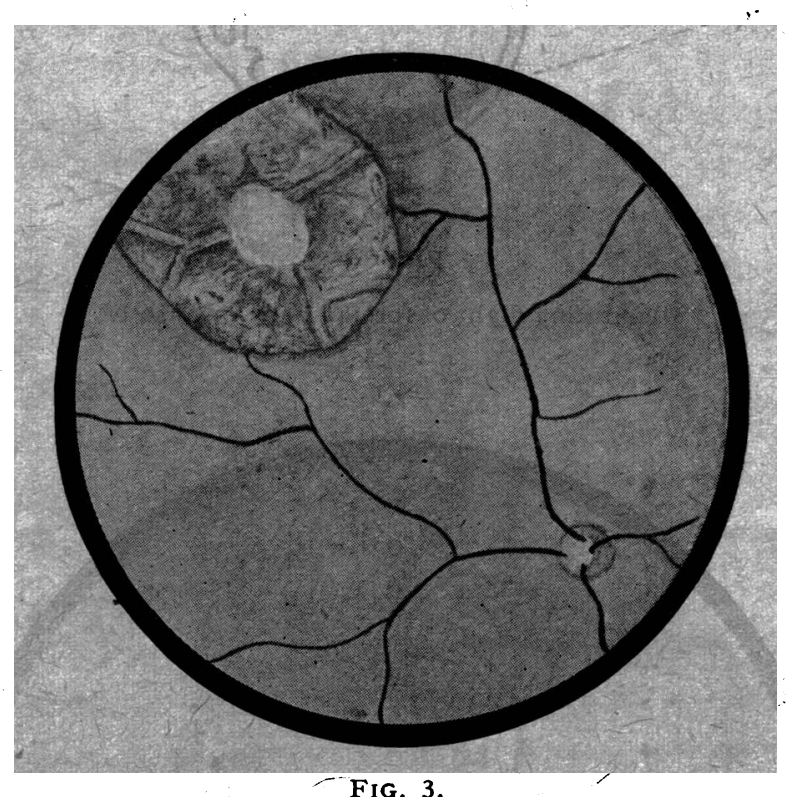

Illustrating fundal appearance in Case 2. Area of choroido-retinal atrophy with a raised white mass.

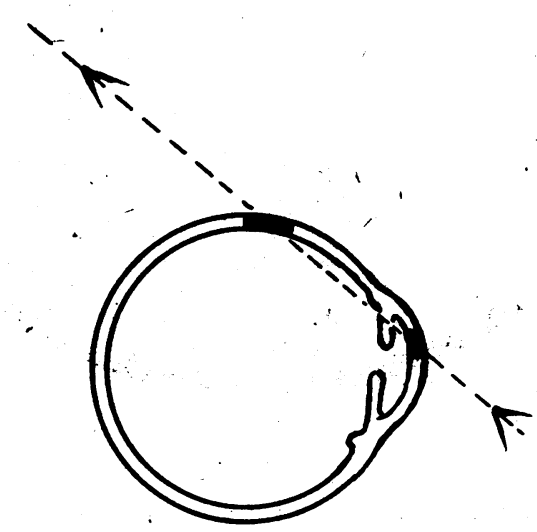

FIG. 4.

Illustrating flight of foreign body in Case 2 . 
circumscribed area of pigmented choroidoretinal change. The most interesting feature was the presence in this area in the " 10 o'clock " meridian of a large bright rounded object about one and a half discs in size. It was immobile and untraversed by blood vessels. Fig. 3 indicates the fundal appearance. The picture was completed by $\mathrm{X}$-Ray indications of a foreign body against the outer orbital wall. Fig. 4 indicates the flight of this foreign body.

This soldier was kept under intermittent observation for two months during which time the eye remained quiet and the fundal picture did not change. The vision was $6 / 9$ throughout. No flare or precipitates were noted with the slit-lamp.

CASE 3.-Cpl. B., aged 27 years. On October 3, 1942, this soldier was hit by a piece of metal which lodged in his right eye. A few days later it was removed by magnet through the anterior route. On October 27,1942 , he came under our observation. The injured eye was almost quiet by then with a corrected vision of $6 / 9$. A penetrating corneal scar and iris hole were present at " 7 o'clock." In the lower inner part of the fundus in the periphery there was a well defined area of choroido-retinal atrophy. In this area was a glistening white rounded mass about $3 / 4$ disc in diameter. Fig. 5 illustrates the fundal appearance and Fig. 6 the flight of the foreign body.

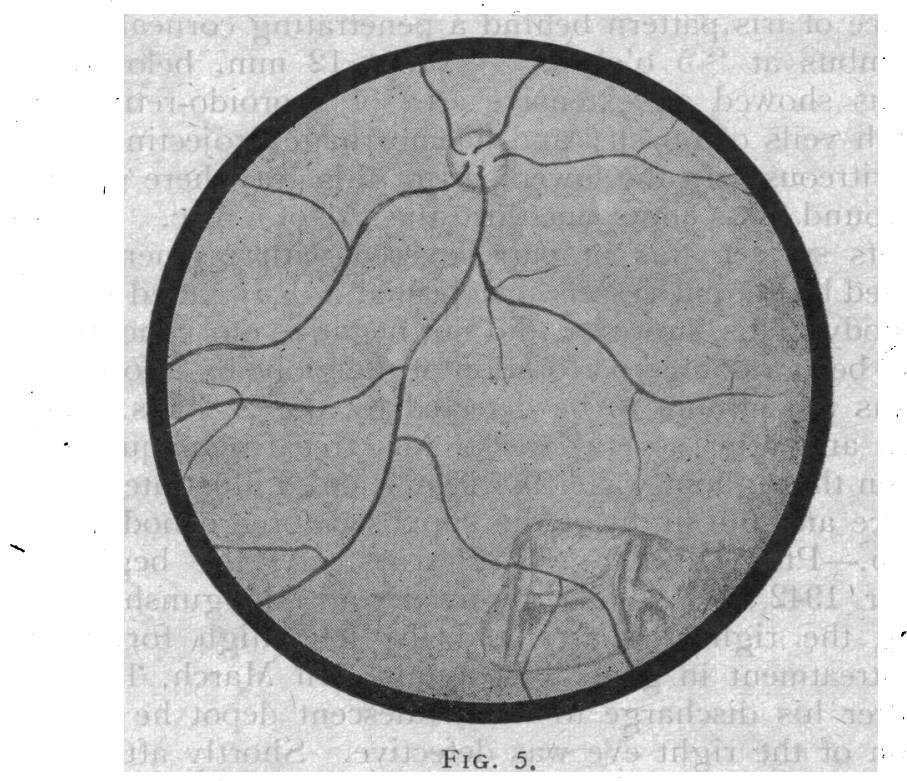

Illustrating fundal appearance in Case. 3. Area of choroido-retinal atrophy with a raised white mass. 


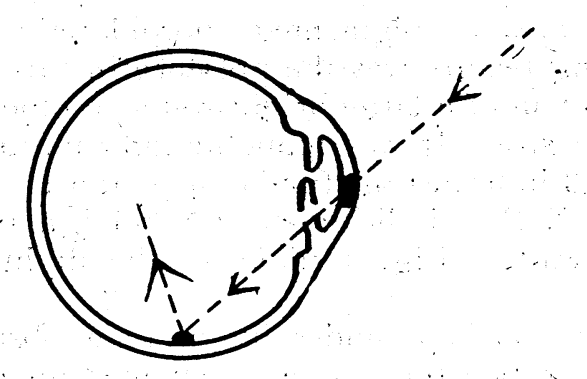

FIG. 6 .

Illustrating flight of foreign body in Case 3.

There does not seem much doubt that the affected fundal area represents either the place of incomplete penetration of the foreign body that later was removed or else the site of exit from the globe of a second foreign body. Slit-lamp examination failed to reveal flare or precipitates. The soldier was discharged to duty seven weeks after the injury.

CASE 4.-Càptain M., aged 28 years. This officer received a shrapnel injury to the left eye on October 23,1942 . Three weeks later he came under our observation. The eye was then slightly irritable, the iris discoloured and an aqueous flare with a few precipitates detectable on slit-lamp examination. There was a disturbance of iris pattern behind a penetrating corneal scar close to the limbus at " 5 o' clock." "About $12 \mathrm{~mm}$. below the disc the fundus showed an extensive area of choroido-retinal disturbance with veils of opacity and haemorrhage projecting forwards into the vitreous. In the lower part of this area there was a solid looking round mass about one third the size of a disc. The whiteness of its sưfface was in part covered with pigment. It was untraversed botinal vessels. Repeated X-Ray faited to reveal a foreign body This, however, did not negative our conclusion that there had befn a double perforation of the globe by a foreign body which was minute to be detected by the X-Ratis. The eye quietened and after several weeks was free from queous flare. The vision thoughout was $6 / 9$. Fig. 7 and 8 illustiate the fundal appearance and the flight of the supposed foreign body.

CASE 5.-P D.C., aged 22 years. At the beginning of November' 1942 this soldier received multiple gunshot wounds involving the righefore-arm and the left thigh for which he received treatment in heneral hospitals. of March, 1943, a few weeks after his discharge to the the vision of the right eye was defective. Shortly afterwards he came under our observation for the first time. He gave a history that the_right eye had been " inflamed" for a few days following 
W'AR, INJURIES OF THE EYE'

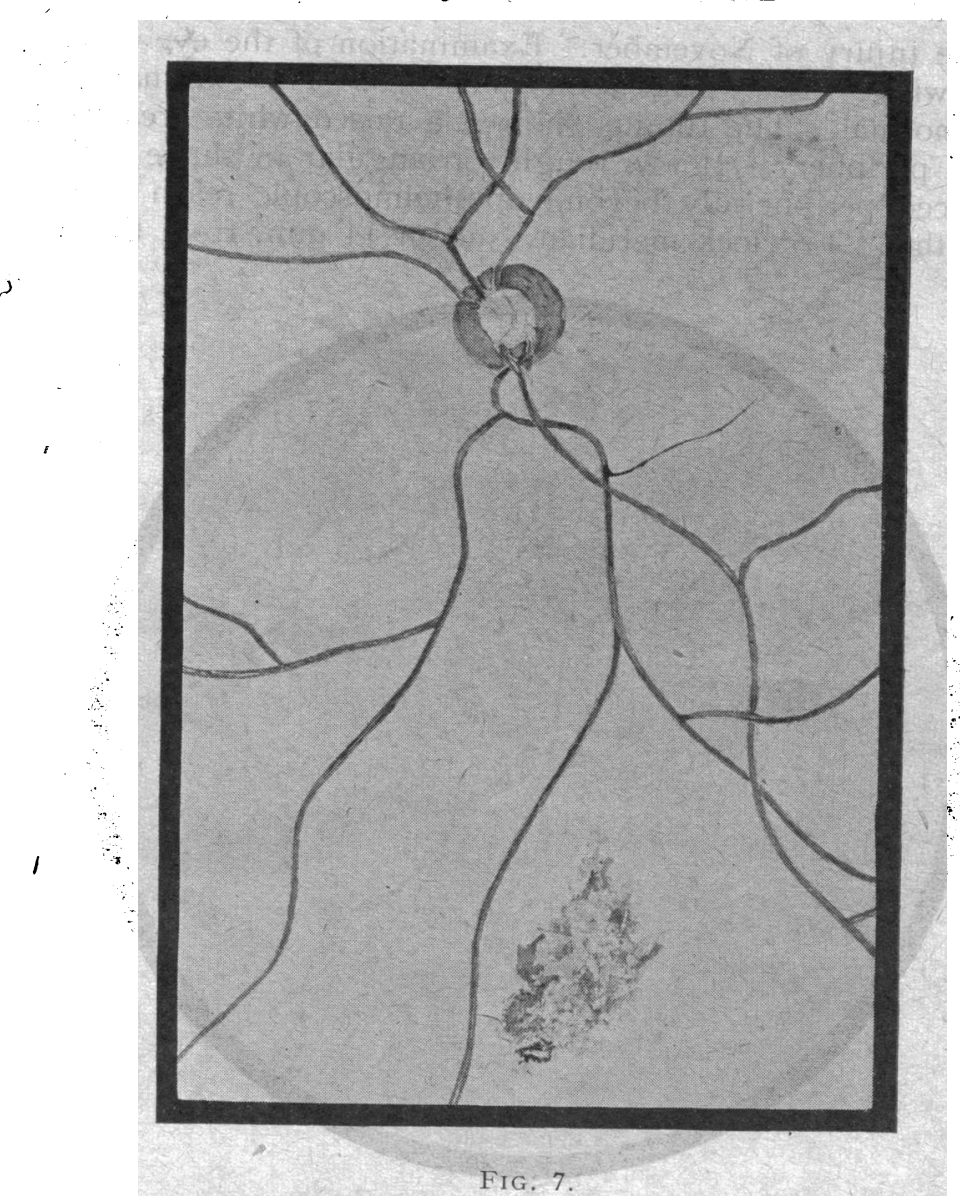

Illustrating fundal appearance in Case 4.

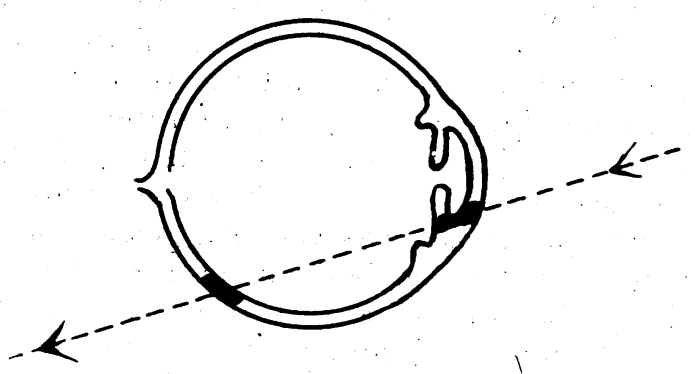

FIG. 8.

Illustrating flight of foreign body in Case 4 : 
the battle injury of November. Examination of the eye revealed the following. The visual acuity was $6 / 9$. The external globe seemed normal. The fundus showed a raised white area in the temporal periphery. It was roughly triangular in shape with its base placed peripherally beyond ophthalmoscopic reach and the apex in the " 3 o'clock meridian" about $14 \mathrm{~mm}$. from the disc.

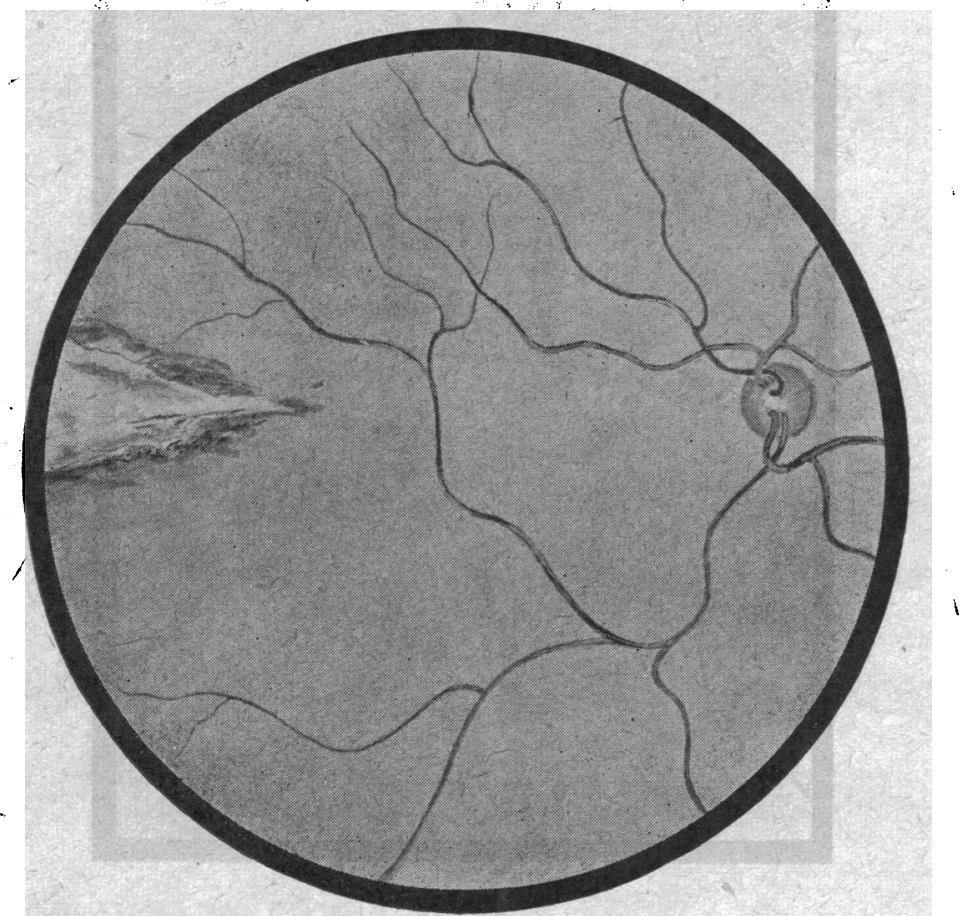

-FIG. 9.

Illustrating the fundal appearance in Case 5. Raised white triangle of tissue.

The position and general appearance of the area was somewhat similar to that described in Case 1 above. The surface was, however, less raised and less white, and the tissue had a less solid appearance. Some pigment was present on the surface. A retinal arteriole crossed the affected area close to its upper edge. The rest -of the fundus was normal. Fig. 9 shows these appearances.

As the fundal appearance was very suggestive of a double perforating injury by a foreign body a more careful search of the surface of the globe was made. A thin scar was found in the sclera. It was $2 \mathrm{~mm}$. long and placed $6 \mathrm{~mm}$. from the limbus just above the " 3 o'clock" meridian. Its appearance corresponded with that of the anterior end of the area seen ophthalmoscopically. It evidently represented the site of entrance of a 
foreign body. The picture was completed by an X-Ray examination which showed a foreign body lying close behind the right globe. It was flake-like and about $0.5 \mathrm{~mm}$. x $0.7 \mathrm{~mm}$. in size.

Fig. 10 is schematic of the path of the foreign body

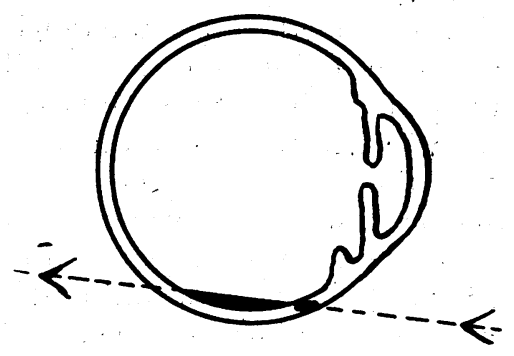

FIG. 10

Illustrating flight of foreign body in Case 5.

CASE 6.-Pte. C. This Italian P.O.W. received a shrapnel wound to his right eye during January, 1941. A few weeks later he came under our observation. A scar was present in the sclera about $9 \mathrm{~mm}$. from the Timbus at "6 o'clock." The vitreous was almost filled with blood but below a white mass could be seen with some haemorrhage on its surface. Bare light perception was present $\mathrm{X}$-Ray showed a large foreign body at the apex of the right orbit. Two months later the vitreous had sufficiently cleared to reveal a detachment of the retina with a large dehiscence in the neighbourhood of the white mass. It could be seen that there were no vessels on the surface of the white mass. As the eye remained irritable and began to shrink enucleation was done on June 21, 1941. The following is the pathological report on the eye :-

Two penetrating wounds were present in the sclera as indicated in Fig. 11. They were 4-5, mm. apart and seemed to be in the relation of entrance and exit wounds. The globe was divided vertically through the optic nerve. In the fundus corresponding

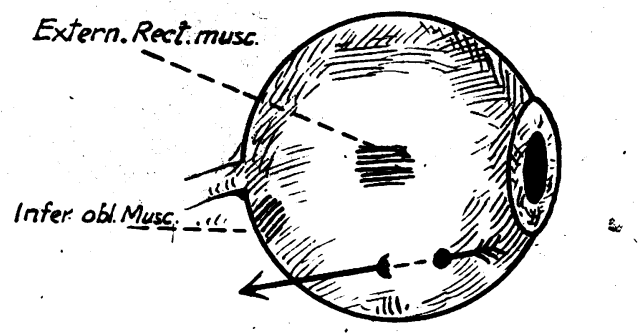

FIG. 11 .

Showing position of scleral wounds in Case 6, and illustrating flight of foreign body. 
to the scleral wounds already noted there was a dense fibrinous tissue. It appeared to be associated with choroid and was in such a position as to represent the track of a foreign body passing between the scleral wounds. The surrounding retina was detached very extensively. The globe appeared normal otherwise. It was embedded in paraffin, sectioned and stained with haemalum and eosin. Histological examination shows a well marked cyclitic membrane to be present. The most interesting changes are opposite a scleral scar which is the site of one of the scleral wounds already noted.' There the choroid is very much thickened by a large knot of fibroblastic tissue some of which with many pigment cells can be seen passing into the vitreous through a gap in the overlying retina. In the thickened choroid and passing some way into the retinal gap are capillary vessels. At one place the thickened choroid is infiltrated with large cells which appear epithelioid or retinal in type. Fig. 12 is a micro-photograph of the area described.

The scleral scar is just out of the photograph below.

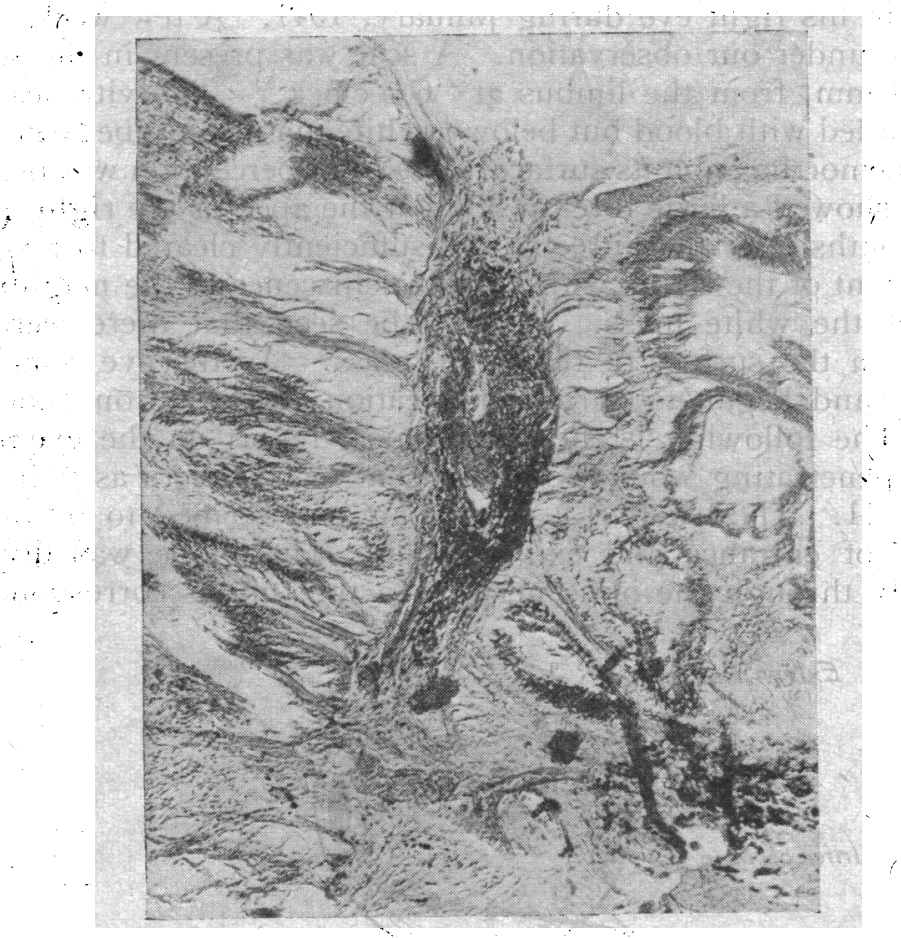

FIG. 12 .

$\therefore$ Section of wound in Case 6 showing choroidal proliferation passing through a gap in the overlying retina. New formed vessels can be seen द.: in the proliferated tissue (compare with fine vessels illustrated in Fig. 2). 
CASE 7.-Pte. S. This cáse was seen in consultation with Major J. Kingsley, A.A.M.C., with whose kind permission it is included in this series. A piece of shrapnel entered the left eye of Pte. S. close to the limbus at " 9 o'clock" and left the globe by penetrating the sclera and external rectus muscle at about " 3 o'clock" as indicated diagrammatically in Fig. 13.

The vision of the eye was reduced to the perception of light. The fundus could not be seen because of intra-ocular haemorrhage. The eye was enucleated when evidence of irritation appeared in

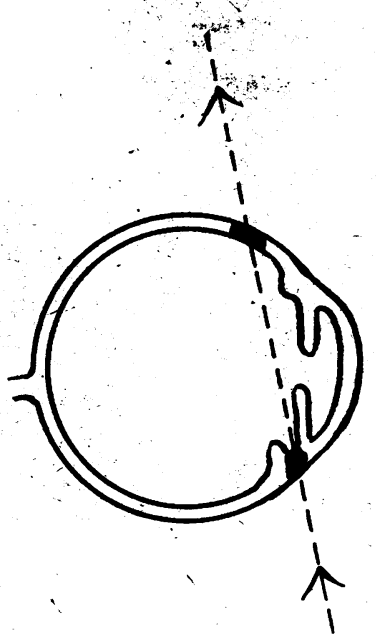

FIG. 13.

Illustrating flight of foreign body in Case 6.

the other eye. The foreign body was found in the outer orbital wall.

The following is the pathological report on the eye:-The scleral scars were identified and the globe divided horizontally through the scars. It contained much haemorrhage.

Microscopic examination shows no evidence of sympathetic disease and is of special interest only in the region of the exit wound. Fig. 14 is a micro-photograph of this region.

A large retinal hole can be seen immediately behind the ora serrata. Projecting through it into the vitreous is a mass of proliferated choroidal tissue. This mass consists of fibroblasts, pigment cells and capillaries. The scleral scar can be seen below.

\section{Discussion}

Both cases in which there was an opportunity for histological investigation showed a massive proliferative choroiditis at the exit 


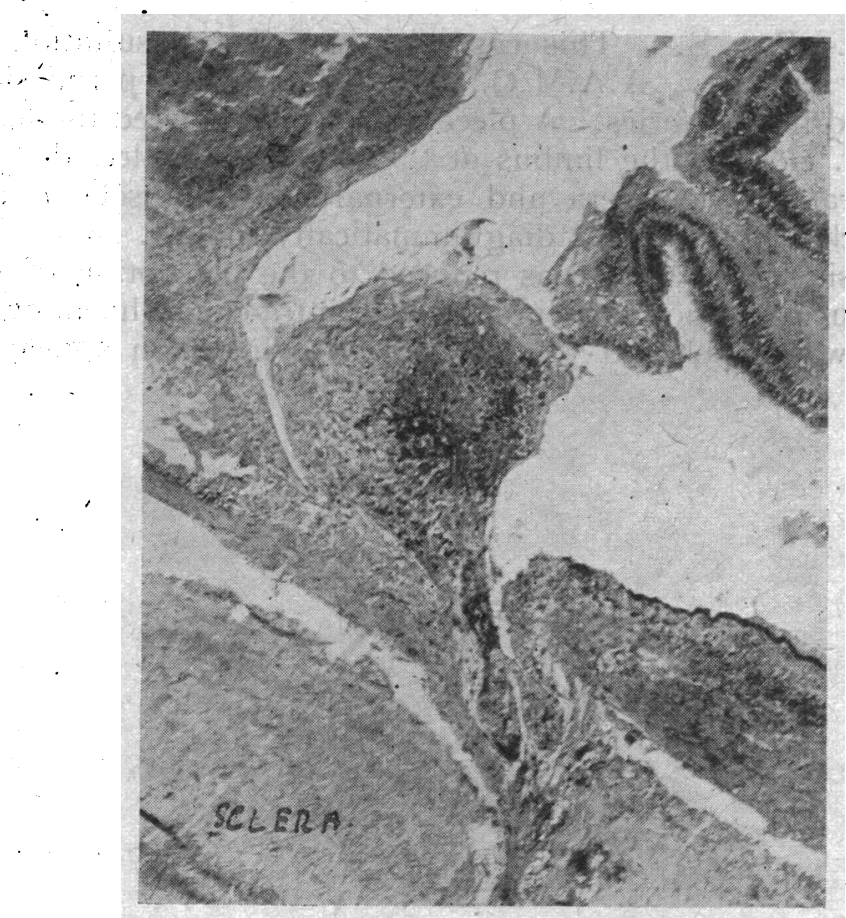

FIG. 14.

Section of wound in Case 7. Proliferated choroidal tissue can be seen passing in almost mushroom form through a retinal gap. The inner part of the scleral scar can be-seen below. Although some subretinal hæmorrhage is present much of the retinal detachment is probably artefact.

wound. Bruch's membrane had been destroyed at the affected place _so that the proliferated tissue had no difficulty in passing inwards through the retinal gap made by the foreign body. The plugging of this gap by the choroid reaction would appear to be purposive in nature. Despite the tear in the overlying retina only two cases showed detachment of that tissue. In these cases a dehiscence at the ora serrata appeared to be the cause of the detachment.

\section{Summary and Conclusion}

(1) Seven cases of double injury to the walls of the eye-ball by foreign bodies are described.

(2) In six cases in which the fundus could be observed ophthalmoscopically, a. well defined raised white mass was seen at the site of the posterior wound.

(3) Two cases which afforded opportunity for pathological - study appear to indicate that the basis of the clinical appearance 
at the posterior wound is a massive proliferative choroiditis observed through a large retinal hole.

We wish to thank Col. J. Biggam, M.C., Commanding (Scottish) General Hospital and Brigadier G. I. Scott, Consultant Ophthalmologist, Middle East Forces, for their kind permission to publish these notes. The Micro-photographs were done in the Hadassah Hospital, Jerusalem. We are grateful to the authorities and to Professor Feigenbaum who made the necessary arrangements. The fundal paintings were done by Dr. J. Kraus.

\title{
SUB-HYALOID HAEMORRHAGE FOLLOWING "T.A.B." INOCULATION
}

BY

\author{
Major J. P. F. LLOYD, R.A.M.C.
}

IT is well known that spontaneous haemorrhages, sometimes severe, may occur in any part of the body following routine immunization with T.A.B. Little is known of the aetiology of this condition; it is suspected that it may be due to a temporary increase in capillary permeability. The following case is reported because it is believed that haemorrhage in the eye has not previously been recorded in this association.

A man aged 36 years, of normal physique and previous good health received his routine injections of T.A.B., the first of 500 millions on February 15 , and the second of 1,000 millions on March 2. Each injection produced a normal reaction. On March 3 he noticed that the vision of the Yeft eye was extremely poor but he did not report sick until some days later.

When examined on March 16, the right eye was normal, having a visual acuity of $6 / 6$. The left eye could only discern hand movements, and an extensive sub-hyaloid haemorrhage was found lying in front of the macular region, to the temporal side. $\mathrm{He}$ was put completely at rest and atropine drops were instilled in the affected eye.. The haemorrhage began to clear slowly, retinal vessels on the temporal side being visible five days later through the vitreous haze.

General investigation showed some chronic bronchitis; the blood. picture was normal. When last seen by me on April 2, absorption of the haemorrhage was continuing but vision was still hand movements only. I am indebted to Major E. F. King, R.A.M.C., for a later report from a convalescent hospital on June 3, which states that "there was still considerable unabsorbed haemorrhage in the left vitreous." 